\title{
1 Estimating available salt volume for potential CAES 2 development: a case study using the Northwich 3 Halite of the Cheshire Basin.
}

\section{Parkes ${ }^{1}$, D.J. Evans ${ }^{1}$, P. Williamson ${ }^{1}$, J.D.O. Williams ${ }^{1}$}

${ }^{1}$ British Geological Survey, Kingsley Dunham Centre, Nicker Hill, Keyworth, NG12 5GG.

\section{Abstract}

The massively bedded rock salts forming the Northwich Halite Member of the Cheshire Basin represent a huge mineral resource, which historically, have been worked by dry mining for rock salt and brine production from both the area of wet rockhead and also from solution-mined caverns. More recently, the halite beds have also provided the host storage horizon for natural gas storage in specifically designed and constructed solution-mined salt caverns. Increasingly, compressed air energy storage (CAES) is being viewed as a viable bulk storage option for surplus electrical energy, which may be through the use of offpeak electricity from both conventional and renewable sources. We describe a novel technique using Esri's ArcGIS ${ }^{\circledR}$ Geographic Information System software, to derive potential storage cavern locations and an estimate of the physical volumes that might be available for storage purposes, including for CAES. The process involves defining the spatial distribution, thickness and insoluble content of the halite beds is described, together with an estimate of the potential physical volumes of solution-mined caverns. Cavern volumes compare favourably with those of current gas storage facilities, which are illustrated in terms of their surface footprints and use of resource.

Keywords: Compressed Air Energy Storage; Halite; Cheshire; Cavern; Arc GIS.

\section{Introduction}

The UK energy networks face a number of challenges in the coming decades, including increased penetration of renewable energy sources, threats to energy security of supply with declining indigenous fossil fuel reserves and increasing reliance on imported fossil fuels, and also decarbonising electricity production to achieve the goal of $80 \%$ reduction in $\mathrm{CO}_{2}$ emissions by 2050 [1]. The transition to renewable energy sources such as wind and solar will introduce natural variability into electricity generation capacity. To meet a pattern of demand that does not follow such variations in generation, there will be a need for fast ramping, back-up generation, supported by reliable forecasting and, importantly, increased bulk storage capacity for electricity generated from renewables.

In 2012 the IMAGES project (Integrated, Market-fit and Affordable Grid-scale Energy $\underline{\text { Storage) }}$ commenced as part of the Engineering and Physical Sciences Research Council's (EPSRC) Energy Storage Grand Challenge: integrating energy storage for future energy networks. A major aim was to assess the various electrical energy storage (EES) technologies capable of providing large, utility-scale, energy storage and deliverability (>100 MW).

To date, pumped hydroelectric (PHS) facilities have been the main bulk energy storage technology, with water pumped to a higher reservoir during off peak, low demand periods and released during periods of peak demand to drive turbines. In many countries however, including the UK, PHS has reached a point of near maximum deployment due to the scarcity of available sites with suitable geographical conditions, long lead times and high construction costs [2]. Apart from PHS, Compressed Air Energy Storage (CAES) 
represents the only other bulk energy storage technology proposed as a potential solution for levelling fluctuating wind-power production and maintaining a system balance $[3,4]$.

With CAES, electricity (energy) generated during off-peak periods is used to compress air to high pressure to then be stored either in above-ground or near-surface pressurized air pipelines (20-100 bars:[5]), or by injecting it into storage below ground (70-100+ bars). During peak load demand periods, the air can then be released to be used in gas turbines to generate electricity.

Underground geological storage can be through the use of: salt caverns [6] (see below); porous rock, either depleted hydrocarbon fields or aquifers, e.g. the aquifer tests at Sesta in Italy [7,8] and Pittsfield and Iowa, both in the US [9,10,11,12]; abandoned mines/purposely mined voids e.g. Norton, Ohio [13]; or lined rocks caverns, e.g. the test adiabatic CAES facility in the abandoned Pollegio-Loderia tunnel, north of Biasca in the Swiss Alps [14,15].

Two commercial 'conventional' (diabatic) CAES facilities are currently operational, using solution-mined salt caverns for storage (Figure 1): the currently rated $320 \mathrm{MW}$ output for $\sim 3-4$ hours ( $960 \mathrm{MWh})$ at Huntorf (Lower Saxony, N. Germany, operational since 1978; [16,17]) and a 110 MW output for 26 hours (2600 MWh) plant at McIntosh (Alabama, USA, operational since 1991; [18]). A third, small 2 MW, near-isothermal (adiabatic) CAES system, was developed and operated between 2012 and 2016 at Gaines in western Texas (USA) by Texas Dispatchable Wind 1, LLC (a subsidiary of General Compression; [19,20,21]). Halite, commonly known as rock salt; the mineral form of $\mathrm{NaCl}$, is the most suitable lithology because it is highly soluble, impermeable to gas, and unless strain rates are very high, deforms by creep and flow rather than by brittle deformation formation or faulting. Any brittle damage is therefore likely to be repaired by subsequent ductile flow arising from crystal plastic deformation and pressure solution processes [22]. These operational plants demonstrate that CAES is viable in solutionmined underground salt caverns, either constructed specifically for compressed air storage, or which remain following cessation of brining operations. In the UK, one CAES plant is currently being planned using salt caverns constructed some $1500 \mathrm{~m}$ below ground at Islandmagee, near Larne in Northern Ireland (Figures $1 \& 2 ;[6,23,24,25]$ ).

The alternative geological storage options to salt caverns are not likely to be developed in the near future due to potential problems of storage integrity and deliverability [12], and/or development costs, which are considerably higher for non-halite storages (Table 1; [26]). For the near future, therefore, salt cavern storages remain the cheapest and most flexible option for CAES; they can handle frequent cycles, have higher injection and withdrawal rates and have a lower share of cushion gas. Given this and the development of thick bedded halite deposits in the UK in which a number of natural gas storage cavern facilities have been developed [27], a principal aim of IMAGES was, therefore, to assess the UK potential for compressed air energy storage (CAES) in solution-mined salt caverns.

\section{UK CAES potential}

The Huntorf plant storage caverns are produced in the Zechstein salts [16] that run extensively across Northern Europe and come onshore within the UK in East Yorkshire as the Boulby and Fordon evaporates, for conventional 1300m CAES [23] these are mostly too deep, although new plans for CAES at depths of $1500 \mathrm{~m}$ from Northern Ireland may change this [24]. In the UK the younger Mesozoic and Cenozoic salts offer a much better depth range, however being bedded rather than domal, these are much thinner than the Zechstein salts limiting cavern height and also have higher insoluble content.

In the UK, all current salt-based storage facilities are associated with storage of natural gas; they are restricted to the onshore Triassic salt beds of the Northwich Halite Member in Cheshire and the Permian salt beds in eastern and north-eastern England. Salt beds of the Triassic Preesall Halite in the East Irish Sea (EIS) are also currently a target for the Gateway gas storage project and plans are advanced for a CAES facility in Permian salt beds onshore in the Islandmagee area of Northern Ireland [24,25]. The development of onshore facilities is in part related to the fact it is technologically simpler and thus cheaper to develop onshore, but also that the storage sites are closer to the required energy markets. 
In terms of the UK salt basins, the Cheshire Basin with its thick massively bedded Triassic halite deposits represents a major region of interest for CAES studies. The massively bedded halites are largely restricted to two thick, massively bedded sequences: a lower (older) Northwich Halite Member and an upper (younger) Wilkesley Halite Member, both of which have been exploited for brine by solution mining (Figure 3; [28,29,30]).

Using a Geographical Information System (ArcGIS ${ }^{\circledR}$ software by Esri), an important aim of the IMAGES project was to estimate for the UK the location and amount of salt available for CAES. In this way, a determination of the potential theoretical cavern physical volumes for the halite deposits of the UK could be made, from which CAES potential might be assessed. Initially the Cheshire Basin was used as a case study to develop the methodology and processes, with the scope to then expand the method to other UK halite-bearing basins.

\section{Cavern Volume Calculation for the Cheshire Basin}

\subsection{Method}

\subsubsection{The Cheshire Basin and Northwich Halite Geology}

The Triassic Northwich Halite Member $(\mathrm{NwH})$ of the Cheshire Basin, already the centre of active gas storage and brine extraction industries, was the focus of initial GIS modelling of the Northwich Halite Member as a potential storage horizon for CAES. This section outlines the modelling approach taken to assess the potential cavern and storage volumes available in the main halite beds of the Cheshire Basin.

The Triassic Northwich Halite Member $(\mathrm{NwH})$, is the main sequence of bedded halite widely exploited for brine production and rock salt, and is the host to recently constructed solution-mined gas storage caverns in the Cheshire Basin (Figures 2\&3; [6,28,29,30]). The operational gas storage facilities demonstrate the capability of large caverns ( $\sim 50 \mathrm{~m}$ radius and up to $130 \mathrm{~m}$ in height) in the halite beds to store gas at high pressure. Further gas storage caverns are planned at King Street [31] and immediately south of Stublach at the Keuper Gas Storage site (Table 2; Figure 2; [6,32,33,34]).

The NwH beds extend eastwards from near-surface to depths exceeding $\sim 1500 \mathrm{~m} \mathrm{bgl}$ (below ground level) against the eastern basin-bounding Wem-Red Rock Fault Zone (WRRFZ; Figure 4; [27]).

In the near surface, the halite beds are affected by a region of wet rockhead: circulating groundwaters cause dissolution of the halite beds leading to collapse of the interbedded mudstone units and subsidence across the zone. Wet rockhead conditions are potentially present in shallower areas, generally between 50-120 m, but may extend down to a maximum of 150-200 $\mathrm{m}[35,36]$. Within the interior of the basin $\mathrm{N}$ $\mathrm{S}$ faults, which appear to have moved syndepositionally during halite accumulation, affect the halite beds with some thickness variations seen in the $\mathrm{NwH}$, the most significant of these faults is the normal, downto-the-east King Street Fault (KSF). The NwH attains thicknesses of over $250 \mathrm{~m}$ : the thickest proven being $283 \mathrm{~m}$ in the Byley borehole [27,32,37], to the SE of Northwich, between the KSF and WRRFZ. Geophysical log correlations show a shallowing and thinning of the Northwich Halite to the west from over $1400 \mathrm{~m}$ in the east, adjacent to the WRRFZ (Figure 5), and also erosion and removal of some of the uppermost halite beds over upthrown fault blocks, as in the area of the Winsford Mine, within the footwall block of the KSF [38].

As a generalisation, the $\mathrm{NwH}$ comprises about $75 \%$ halite and $25 \%$ mudstone in the Northwich, Winsford and Chester areas [20]. The halite is mostly massive and monominerallic, with minor thin laminae $(<1 \mathrm{~mm})$ of anhydrite and non-ferroan dolomicrite. Muddy ('dirty') salt beds are developed in which synsedimentary halite crystals displace mudstones and are known as Haselgebirge facies. The halite in places has also experienced multiple episodes of extensive recrystallization. Borehole cores and geophysical logs reveal that the $\mathrm{NwH}$ contains numerous thick beds of very clean to muddy halite interbedded with thinner beds of predominantly mudstone. The mudstones can attain thicknesses of up to $10 \mathrm{~m}$ in the case of the 
Thirty Foot Marl [39,40]. The Northwich Halite shows a remarkably uniform geophysical log response along the length of the basin and in an east-west direction, with individual dirtier halite intervals, mudstone and halite beds traced over $50 \mathrm{~km}$ [41].

The structureless salt/marl beds spatially show every gradation from salt with less than $10 \%$ of silty mudstone, to a mudstone matrix with large isolated halite crystals (haselgebirge facies). Overall in the Winsford area of the Cheshire Basin, it is estimated that the total content of clay and silt through discrete mudstone bands and disseminated material in the Northwich Halite is the equivalent of $53 \mathrm{~m}$ thickness, or about $24 \%$ of the Northwich Halite by volume [39]. As described below, this impacts the cavern volumes, because although some of the finer muddy material will be held in suspension and removed from the cavern with the brine, the majority falls to the base of the cavern, filling the sump area. With a bulking factor to the fallen material, this accounts for $25-30 \%$ of the mined volume such that for a cavern $100 \mathrm{~m}$ in height, the bottom $\sim 25-30 \mathrm{~m}$ is filled with fallen insoluble material. A further consideration is that brine remains trapped within this sump material, giving rise to moisture in the cavern during gas storage operations.

\subsubsection{Depth Ranges for CAES}

149

150

151

152

153

The depth ranges chosen for the CAES cavern study were based upon published information. Recent publication [23] suggest the operational window for CAES caverns lies between 500 to $1300 \mathrm{~m}$ (Figure 1), based upon operating pressures being directly dependent on depth and power plant components. More recently, it has been suggested that a breakthrough in compressor and turbine technology would enable CAES deployment to greater depths than previously considered, with $1500 \mathrm{~m}$ seen as the limit [25]. As gas storage caverns are also developed at shallower depths of $\sim 250 \mathrm{~m}$ (Figure 1; [23]), the lower depth of 250 $\mathrm{m}$ has been included in this study in order to assess maximum available cavern volumes. Hence we have assessed the UK cavern volume potential over the depth ranges: $250-1300 \mathrm{~m}, 250-1500 \mathrm{~m}, 500-1300 \mathrm{~m}$ and 500-1500 m."

\subsubsection{Calculation of Raw (physical) Cavern Volumes}

Structure contour maps of the top and base Northwich Halite Member $(\mathrm{NwH})$ were generated by extracting the stratigraphic information from boreholes and contouring the depths below ground level. The thickness of the halite beds were similarly obtained from the borehole data. The top and base $\mathrm{NwH}$ surfaces were digitised and used to construct a 3D volumetric model using the geological modelling package, GOCAD. This was used to assess the subsurface disposition of the halite beds and to calculate volumes of salt. The model incorporated the main King Street Fault, with up to $600 \mathrm{~m}$ normal downthrow to the east at the top halite beds in the north of the Cheshire Basin (Figure 4), but smaller faults such as the down-west Winsford and down-east Moberley faults are not included for reasons of scale and lack of controlling data (Figure 5).

In order to derive the area and volume of salt that might be suitable for cavern construction, a series of constraints ('buffers') were applied to the geometric model of the $\mathrm{NwH}$, to produce minimum casing shoe (and cavern top) and basal surfaces, as illustrated in Figure 6:

1. The minimum storage cavern height is set to be $20 \mathrm{~m}$ (but the maps and extracted data would permit large minimum cavern sizes to be assessed). Such cavern heights are unlikely to be utilised in the UK, but is considered here based on storage cavern dimensions in some thin bedded halites elsewhere in the USA [31].

2. The minimum depth of the casing shoe $\left(z_{M I N}\right)$ was set at either $250 \mathrm{~m}$ or $500 \mathrm{~m}$, based upon the minimum depths of gas storage caverns in the region and the $500 \mathrm{~m}$ depth limit of casing shoe for CAES caverns described by Crotogino and co-workers [23].

3. The maximum depth of the casing shoe $\left(z_{M A X}\right)$ was set at $1300 \mathrm{~m}$ or $1500 \mathrm{~m}$, based on either Crotogino and co-workers, or the more recent depths for CAES proposed by Gaelectric [25].

4. Where the top of the halite beds is greater than $250 \mathrm{~m}$ or $500 \mathrm{~m}$, the casing shoe is set $10 \mathrm{~m}$ below the top of the halite, defining a surface of top halite plus $10 \mathrm{~m}$ 
5. For cavern integrity purposes, the roof of a cavern is set $10 \mathrm{~m}$ below the casing shoe depth $-\mathrm{a}$ 'roof salt' resulting in $20 \mathrm{~m}$ thickness left where the top of the halite beds are at depths greater than $250 \mathrm{~m}$ or $500 \mathrm{~m}$. For gas storage purposes, HSE requires at least $3 \mathrm{~m}$ of salt below the casing shoe [42]. Elsewhere, a minimum of $10 \mathrm{~m}$ roof salt was suggested for caverns in 'thin-bedded halites' [43].

6. For cavern integrity purposes, a $10 \mathrm{~m}$ thickness of halite is left beneath the base of the cavern ('floor salt'). A distance of 5-10 m was suggested for the Preesall gas storage proposal [44].

This means that for, example, the cavern top surface for $z_{M I N}=250 \mathrm{~m}$ surface is actually at a range of depths; where the salt top is $\leq 250 \mathrm{~m}$ the cavern top is at $260 \mathrm{~m}$ and where the salt top is $>250 \mathrm{~m}$ the cavern top is at a depth of (salt top depth $+20 \mathrm{~m}$ ).

The modelled cavern top and base surfaces were converted into regular grids with 50 x $50 \mathrm{~m}$ grid cell size and exported to the GIS for further analysis. The exported surfaces provided areas of usable salt distribution within the Cheshire Basin and against which a theoretical cavern framework could be constructed. The framework maximised cavern distribution density and salt usage, but was limited by the following engineering constraints, based upon typical gas storage cavern designs in the UK [34, 45].

1. Cavern diameters were set at $100 \mathrm{~m}$ (50 m radius, $\mathrm{R})$

2. Cavern pillar widths between caverns were set at $150 \mathrm{~m}$, or $3 \mathrm{R}$ - each cavern must have a minimum wall thickness to ensure cavern stresses do not interact (effectively an 'unperturbed stress' salt zone)

3. Caverns were set in a regular, hexagonal close-packed grid pattern

It is important to note that the optimal cavern wall distance is not fixed and due to variable operating pressures, related to cavern depth or variable cavern size, it may change. For this study and irrespective of depth, all the caverns had a fixed radius of $50 \mathrm{~m}$ and a fixed pillar width of $150 \mathrm{~m}$, based on modelling for the planning application for the Preesall Gas Storage project [45].

The ArcGIS ${ }^{\circledR}$ zonal statistics tool was used to extract statistics for each calculated cavern within the cavern framework template including maximum cavern heights and insoluble content. The zonal statistics tool uses a feature dataset to define zones for which the zonal statistics can be output from a raster input. For this study, the cavern framework template was used as the feature dataset and mean values were calculated for each zone (cavern) from the associated values in either the salt thickness raster, when calculating maximum cavern height or salt insoluble content raster.

The aim of this study was to produce a maximal estimate of the volume available for CAES in the Cheshire Basin, therefore the maximum cavern height as determined by the thickness of the halite beds. However, most active gas storage facilities exploit less than the full halite bed thickness for various reasons that include the fact a smaller volume is required for natural gas due to the higher energy per unit volume compared to air, geomechanical considerations including retention of cavern stability, as well as reasons of economy.

Using the maximum cavern heights raw cavern volumes were estimated assuming simple cylindrical cavern shapes, which is an oversimplification, as the top and base of storage caverns require somewhat squat dome/saucer shapes for both cavern roof stability and gas tightness: the difference in geometry leads to a small reduction in cavern volumes. This volume loss was judged as not significant for the current study, given the regional scale of the maps and other variables (e.g. the insoluble content - section 3.1.4.2).

\subsubsection{Cavern Volume Calculations and Buffering}

In order to calculate more realistic potential cavern volumes a number of calculations and corrections were applied to the raw cavern volumes from section 3.1.2, these included shape corrections, consideration of insoluble content of the halite, and buffering of areas in which the halite beds are/would be inaccessible. 


\subsubsection{CAVERN SHAPE FACTOR}

In reality, no solution-mined cavern develops perfectly with smooth sides or to the limits of the geomechanical envelope in all directions. Cavern walls develop a roughness due to many factors, but most usually due to the effects of interbedded mudstones during halite dissolution, particularly when any dip to the beds is present $[46,47]$. In an attempt to obtain realistic final cavern volume estimates, an average shape factor of 0.7 was applied to account for irregular cavern walls ('roughness') and the non-perfect dissolution of the halite beds. This was based on the figure value used by Macdonald [45] in the planning application for the Preesall Gas Storage project.

\subsubsection{Residual Insolubles Content in the Northwich Halite Member}

The NwH contains insoluble mud and siltstone either as disseminated material in the halite beds, or as distinct interbeds, ranging from a few millimetres to several metres in thickness. The thickest mudstone known as the Thirty Foot Marl, in the lower third of the NwH Formation [39]. Whilst some of the finer insoluble material is carried out of the cavern during solution mining, most falls to the base of the cavern (the 'cavern sump'), thereby reducing the total mined volume. The amount of residual insoluble material is a function of the location of the cavern within the sedimentary basin, lesser percentages of insoluble material is found in the thicker halite beds in the basin centre. Earp and Taylor [39] estimated an average $25 \%$ insoluble material for the $\mathrm{NwH}$, this value is used as an initial estimate to constrain cavern volumes. A more advanced investigation using downhole geophysical logs was also undertaken to estimate the insoluble content of the NwH and to better constrain volume reductions. Logs were utilised from a number of hydrocarbon exploration boreholes, a British Geological Survey stratigraphic borehole (Wilkesley 1), and a more recent gas storage appraisal borehole within the Cheshire Basin (Byley 1).

Downhole electrical logging tools measure properties related to resistivity and acoustic parameters, as well as giving indications of radioactivity, such as natural gamma radiation. These can be used to estimate lithology (e.g. mudstone or salt) and other rock properties such as formation porosity and fluid saturations.

Due to the mixed vintage of the available digital well log data (most wells pre-date the 1990's, and date as far back as 1960), not all of the wells were logged using modern tools, which have generally greater sensitivity and resolution. Furthermore, being mostly concerned with potential oil and gas reservoirs buried at deeper depths, only rudimentary logging was generally carried-out over the $\mathrm{NwH}$ interval. In addition, where the NwH was penetrated in the shallower subsurface (such as in the Knutsford 1 well), it is possible that the logging was conducted through casing, reducing the quality of the logs acquired. The single consistent dataset available, comprises of Gamma Ray (GR) logs, which provide a measurement of the radioactivity of the formations encountered by the logging tool. The GR log is commonly used as an indicator of the shale content of sedimentary strata, because radioactive elements are concentrated in clay minerals in mudstone. Halite however, if relatively clean (i.e. is mainly $\mathrm{NaCl}$ and containing little mudstone content), emits very few gamma rays, resulting in a low GR reading. As observed on geophysical log data through the $\mathrm{NwH}$ and its equivalent Preesall Halite, the bedded halite contains $\mathrm{cm}-$ metre-scale stringers and beds of shale, while haselgebirge facies can contain up to $80 \%$ mud content [ 41 , 48]. The lowest end-member GR values within the $\mathrm{NwH}$ correspond to pure halite.

In the Cheshire Basin, GR logs through the NwH are available for twelve wells. The insoluble content of the $\mathrm{NwH}$ was calculated from the log data for each individual well, by identifying the end-member GR values predicted to correspond to halite and mudstone (Figure 7). For clean halite, containing very few or no clay minerals, the 'halite' values were selected based on the average of the lowermost halite values within the well, while the 'mudstone' values were selected based on an average of the lowermost GR values of the shale-dominated overburden (Figure 7), or in some cases the underlying Bollin Mudstone Formation [39]. The GR logs were then normalised between the chosen 'halite' and 'mudstone' values for each well, so that the resulting volume of clay curves (which represent the fraction of clay minerals in the mudstone at each discrete logging increment) are comparable between wells. This method assumes that the insoluble content of the $\mathrm{NwH}$ comprises entirely clay minerals, volumetrically the most important insoluble material and neglects the small amounts of anhydrite or other insoluble minerals, which are known to be present in small quantities within the $\mathrm{NwH}$. 
The average insoluble content was then calculated for the main NwH interval from the normalised logs in each well, and multiplied by the thickness of the layer to generate the overall thickness of insoluble content. Ideally the analysis would be calibrated to laboratory measurements of insoluble content from core samples, however no such data were available for the Cheshire Basin. Alternatively, bulk density log data, which relate to the density of the rock matrix material, porosity and density of pore fluids, were available for a single well (Burford 1), which was used to test the result from the GR analysis. Using the typical apparent bulk density of halite $\left(2.04 \mathrm{~g} / \mathrm{cm}^{3}\right)$ and shale $\left(2.5 \mathrm{~g} / \mathrm{cm}^{3}\right)$ measured by density logging tools [49] the density log was normalised and an average insoluble content calculated. The calculated insoluble content from the GR and bulk density analyses in the Burford 1 well, differed by only $2 \%$, validating the analyses of insoluble content based only on GR logging.

286 The insoluble content for each wells was plotted in ArcGIS ${ }^{\circledR}$ and used to contour and map the insoluble content around the basin (Figure 8). The insoluble content percentage increases toward the edge of the basin due to a combination of factors, including the increased input of terrestrial material from the basin edges and the reduced amount of halite deposition due to the shallower water depth. This map permits calculation of an insoluble content for each cavern location for input into the cavern volume and exergy calculations.

The initial insoluble factor, both mapped and estimated average (25\%), requires adaptation to account for the inefficiency of mechanical sweeping (remaining insoluble percentage) and uneven insoluble stacking (bulking factor). This study adopted mean values from the Preesall gas storage proposal [45] for the bulking factor (1.5) and remaining insoluble percentage $(86.5 \%)$. For the estimated average mean insoluble content of $25 \%$, these give a final insoluble factor of 0.32 .

\subsubsection{Inaccessible Halite Volumes}

Clearly, neither the generation of the top and base $\mathrm{NwH}$ maps, nor the determination of cavern locations, take into account areas in which it would not be possible to locate caverns due to land-use considerations and potentially detrimental geological features. To account for these inaccessible regions of halite, identify realistic remaining areas of halite for CAES cavern development and calculate potential usable halite and cavern volumes, a series of buffers were generated. Buffering in Arc GIS produce's fixed distance exclusion areas for various feature datasets and combines these to produce a total exclusion area. For this study, and in line with standoff distances used at a number of gas storage facilities, a buffer of $150 \mathrm{~m} \mathrm{(3x}$ maximum cavern radius) was applied to the various off-limit cultural, infrastructure and geological feature datasets (Figure 9). Excluded areas included urban areas, protected areas, major infrastructure such as roads, rail lines, canals and mines and existing salt cavern gas storage facilities and geological features such as large faults including the major intrabasinal King Street Fault and areas of wet rock head.

The current determination of cavern locations and buffering of inaccessible salt regions can only serve to assess the general halite resource and any areas selected for further study would require additional detailed site characterisation before caverns were constructed.

\subsection{Results}

The study has produced an initial estimate of possible salt storage cavern locations and physical cavern volumes in the massively bedded Triassic NhW of the Cheshire Basin (Table 3). This data can be used in an assessment of the potential exergy storage volume using caverns for CAES, related to renewable energy or conventional energy sources during off peak periods [50].

A total theoretical cavern number and volume was initially derived for the optimal CAES depth range 500-1300 m quoted by Kepplinger \& Donadei [23]. In addition, cavern numbers and volumes were calculated for the depth range $500-1500 \mathrm{~m}$, to take into account the latest views on CAES caverns operating at around $1500 \mathrm{~m}$ in Northern Ireland [24]. A further set of cavern data is also derived for the depths 250-1300 $\mathrm{m}$ and 250-1500 $\mathrm{m}$ to reflect the gas storage caverns developed at these depths at the 
Hole House and Hilltop Farm storage facilities in the Cheshire Basin and which operate in the 50-100 bar window of Crotogino and co-workers (Table 1; Figure 1; [23,26]).

Individual cavern volumes across the all examined depth intervals range from 0.036 to $1.032 \mathrm{mcm}$. These minimum and maximum values are found in the 250-1300 and 1500m mapped insolubles range respectively. The increased usable salt thickness and the larger range in insoluble values either side of the $25 \%$ average explain this. Once the total area of halite beds is buffered, against infrastructure and other features that would prevent a cavern being placed in any particular area, extensive areas of available halite beds still exist (Table 3) with theoretical caverns that have large (physical) volumes (Table 3). For the depth range 250-1300 and $1500 \mathrm{~m}$, between $\sim 16,100$ and $\sim 16,600$ potential locations exist for a $100 \mathrm{~m}$ diameter cavern. For the $500 \mathrm{~m}$ and deeper range, this is reduced to between $\sim 7,350$ and 7,800 potential locations for the same $100 \mathrm{~m}$ cavern diameter.

The available cavern volumes have been calculated for the various depth ranges using two methods: an average $25 \%$ insoluble content and the insoluble calculated from geophysical logs and mapped over the basin. The average of $25 \%$ is the industry standard used in the Chester, Winsford and Northwich part of the Cheshire Basin [39]. It is important to see how volumes calculated using this average vary compared to the mapped insoluble values because for some basins the spatial borehole data or geological understanding is not available to create an accurate insoluble distribution map. Overall, the $25 \%$ value is adequate as a first approximation for the insoluble content in the Cheshire Basin, particularly in the deeper and thicker regions of halite beds. However, as illustrated by the map of calculated insolubles (Figure 8), the insoluble content of the $\mathrm{NwH}$ varies across the Cheshire Basin and final cavern volumes show that for any one-depth range, using an average $25 \%$ insoluble content over estimates the total cavern volumes available in relation to using mapped insoluble values derived from geophysical logs. This is illustrated by the 250-1300 m depth range, where the volumes for the total set and reduced caverns are 7,710 and $1,830 \mathrm{mcm}$ for $25 \%$ insolubles, compared to 6,200 and $1,400 \mathrm{mcm}$ for the mapped insolubles (Table 2). Calculations of individual modelled cavern volumes using either the 'standard' $25 \%$ content, or that calculated from the well logs around the Stublach region can be analysed for accuracy by comparisons with sonar data and cavern volumes published from operational caverns at the Stublach gas storage facility (Figure 10; [33,34]). The total volume of an operational gas cavern at Stublach is calculated from sonar data to be $580,000 \mathrm{~m}^{3}$, with $210,000 \mathrm{~m}^{3}$ of this occupied by insoluble residue, leaving a final usable volume of $\sim 370,000 \mathrm{~m}^{3}$. The cavern volumes indicate an insoluble content of $36 \%$, but the actual volume of insolubles in the halite beds will be slightly lower than this due to the bulking factor. The modelled caverns in the Stublach region have an insoluble factor range (inclusive of the bulking factor) of 0.290.34 , which is in line with the $36 \%$ insoluble reduction measured in the Stublach cavern. The modelled caverns have a reduced volume range of 788,017-1,032,449 $\mathrm{m}^{3}$, which is greater than the $370,000 \mathrm{~m}^{3}$ cavern volume at Stublach. This is because the storage facility at Stublach only utilises a narrow salt interval at a depth range of 518-600 $\mathrm{m}$ to give a cavern height of $72 \mathrm{~m}$ whereas the modelled caverns maximise the thickness of the halite beds present, with a height range of 212-270 $\mathrm{m}$, following the various roof and floor salt reductions (Figure 10; [33,34]).

To illustrate the areas and physical cavern volumes involved in these figures, a $1 \%$ subset of modelled caverns with a minimum 100m height, in Cheshire, for the 500-1500 m depth range would number roughly 16 caverns. Cavern height was restricted to $100 \mathrm{~m}$ and above to align with Huntorf (caverns are $150 \mathrm{~m}$ high) [16] and active gas storage caverns in the Cheshire Basin (see table 2). A facility of 16 caverns is in the mid-range of the current UGS facilities in the Cheshire basin which have between four (Hole House - counting EON and Ineos Holford as one facility) and 20 (Stublach) caverns (Table 2 and Figure 11). Thus, in Cheshire, just $1 \%$ of the current available salt could support a viable storage facility and ignoring cavern distribution, there is the potential for upward of $100 \mathrm{new}, \sim 16$ cavern, storage facilities within the Cheshire basin. This represents a maximum number, as not all cavern locations would likely be available or suitable in terms of possible land-use issues, or the nature of the halite beds and/or geological features present. 


\subsection{Conclusions}

372

373

374

375

376

377

378

379

380

381

382

383

384

385

386

387

388

389

390

391

392

393

394

395

396

We have reviewed storage cavern development in massively bedded halite deposits in the Cheshire area for compressed air storage and potential cavern volumes that might be generated. The review included use of a novel technique using Esri's ArcGIS ${ }^{\circledR}$ Geographic Information System software, to derive potential storage cavern locations and an estimate of the physical volumes that might be available for storage purposes. The main conclusions from the study are summarised below:

- The study has produced an initial estimate of possible salt storage cavern locations and physical cavern volumes in the massively bedded Triassic NhW of the Cheshire Basin (Table 2).

- The largest individual cavern volume of $1.015 \mathrm{mcm}$ was found at the depth interval $250-1300 \mathrm{~m}$ (also then obviously the 250-1500m depth range). The depth range $250-1500 \mathrm{~m}$ had the largest total volume $(7930 \mathrm{mcm})$ and cavern number (16607 caverns). These numbers assume an average $25 \%$ insoluble content.

- Infrastructure buffering had a major effect on the total cavern volumes; for the depth range of 500$1300 \mathrm{~m}$ the total volume reduced by $73.5 \%$ (assuming $25 \%$ insoluble content) due to buffering.

- More accurately mapping the insoluble content had a major effect on the total cavern volumes; for the depth range of 500-1300m the total volume reduced by $19.6 \%$ compared to using an average $25 \%$ across the whole basin.

- If cavern height is restricted to $100 \mathrm{~m}$ to align with Huntorf [16] and active gas storage caverns in the Cheshire Basin (see Table 2), then for the 500-1500 m depth range, there is potential for approximately 1600 caverns in the Cheshire basin.

- In Cheshire, just $1 \%$ of the current available salt could support a viable (100m cavern height) storage facility and ignoring cavern distribution, there is the potential for upward of 100 new, $\sim 16$ cavern, storage facilities within the Cheshire basin.

- Physical cavern volumes can be used in an assessment of the potential exergy storage volume using caverns for CAES, related to renewable energy or conventional energy sources during off peak periods [50].

\section{Acknowledgements}

This research was conducted by the IMAGES (Integrated, Market-Fit And Affordable Grid-Scale Energy Storage) project, contract number GA/11F/106, funded by the UK government through EPSRC (Engineering and Physical Sciences Research Council).

We thank Mr Ed Hough and Dr Jon Busby for comments on early drafts of the paper. The paper has benefitted from the helpful comments of four reviewers, to whom thanks are extended.

This paper is published with permission of the Executive Director of the British Geological Survey (NERC).

\section{References}

[1] DECC. 2008. Climate Change Act 2008. UK Government, Department of Environment and Climate Change (DECC), legislation. https://www.legislation.gov.uk/ukpga/2008/27/contents

[2] Chen, H., Cong, T.N., Yang, W., Tan, C., Li, Y. \& Ding, Y. 2009. Progress in electrical energy storage system: A critical review. Progress in Natural Science, 19, 291-312.

[3] Fertig, E. \& Apt, J. 2011. Economics of compressed air energy storage to integrate wind power: A case study in ERCOT. Energy Policy, 39, 2330-2342. 
413 [4] Salgi, G. \& Lund, H. 2006. Compressed air energy storage in Denmark: a feasibility study and an 414 overall energy system analysis. In: World renewable energy congress, IX Florence, Italy, 2006.

415 [5] Ibrahim, H., Ilinca, A. \& Peroon, J. 2008. Energy storage systems - Characteristics and comparisons. 416 Renewable and Sustainable Energy Reviews, 12, 1221-1250.

417 [6] Crotogino, F., Schneider, G-S. \& Evans, D.J. 2017. Renewable energy storage in geological 418 formations. Proceedings of the Institution of Mechanical Engineers, Part A: Journal of Power and Energy, $419 \quad 1-15$.

420 [7] Ter-Gazarian, A. 1994. Chapter 7: Compressed air energy storage. Energy Storage for Power Systems. 421 Peter Peregrinus Ltd., on behalf of the Institution of Electrical Engineers, London, UK. Redwood Books, 422 Trowbridge,Wiltshire,197pp.https://books.google.co.uk/books?id=5VMotgCfJmAC\&pg=PA118\&lpg= $423 \quad$ PA118\&dq=compressed+air+sesta+italy\&source=bl\&ots=XLXOU7exRX\&sig=Q3 46bb17tTmKc610 bwnJ8sHKHQ\&hl=en\&sa=X\&ei=vPSrVIe5B6Le7AbAloGwDw\&ved=0CCoQ6AEwAQ\#v=onepage\& $\mathrm{q}=$ compressed $\% 20$ air\%20sesta\%20italy $\& \mathrm{f}=$ false

[8] Greenblatt, J.B., Succar, S., Denkenberger, D.C., Williams, R.H. \& Socolow, R.H. 2007. Baseload wind energy: modeling the competition between gas turbines and compressed air energy storage for supplemental generation. Energy Policy, 35, 1474-1492.

[9] Istvan, J.A. 1981. Compressed Air Energy Storage Aquifer Field Test Conceptual Design, Construction, and Operation. In Proceedings of the International Conference on Seasonal Thermal Energy Storage and Compressed Air Energy Storage, Vol. 2, 584-591 pp, CONF-811066, National Technical Information Service, Springfield, Virginia.

[10] Allen, R.D., Doherty, T.J., Erikson, R.L. \& Wiles, I.E. 1983. Factors Affecting Storage of and the U.S. Department of Energy under contract DE-AC06-76RLO 1830. Report number PNL-4707, $157 \mathrm{pp}$.

[11] Allen, R.D., Doherty, T.J. \& Kannberg, L.D. 1985. Summary of selected compressed air energy storage sites. Report prepared by Pacific Northwest Laboratory for Battelle and the U.S. Department of Energy under contract DE-AC06-76RLO 1830. Report number PNL-5091, 112 pp. http://www.osti.gov/scitech/servlets/purl/5872515-nnHCP0/

[12] Schulte, R.H., Critelli, N. Jr, Holst, K. \& Huff, G. 2012. Lessons from Iowa: Development of a 270 Megawatt Compressed Air Energy Storage Project in Midwest Independent System Operator. A Study for the DOE Energy Storage Systems Program. Report prepared by Sandia National Laboratories, Sandia Report, Report Number: SAND2012-0388, 97 pp.

[13] Van der Linden, S. 2010. Wind Power: Integrating Wind Turbine Generators (WTG's) with Energy Storage, Wind Power, S M Muyeen (Ed.), 23 pp, InTech, Available from:

http://www.intechopen.com/books/wind-power/wind-power-integrating-wind-turbine-generators-wtg-swithenergy-storage

449 [14] Zavattoni, S., Barbato, M., Geissbühler, L., Haselbacher, A., Zanganeh, G. \& Steinfeld, A. 2014. 450 CFD modelling and experimental validation of the TES system exploited in the Pollegio AA-CAES pilot plant. Swiss Competence Centers for Energy Research, Fifth Heat and Electricity Symposium, 1 pp. http://repository.supsi.ch/7878/1/SCCER-5th-symposium-PSI-A1.pdf

[15] Deign, J. 2017. ALACAES seeks CAES partners. Energy Storage online report posted March 22, 2017. http://energystoragereport.info/alacaes-seeks-partners-caes-quest/\#sthash.sf9E7kfC.dpbs 
http://www.rwe.com/web/cms/mediablob/en/391748/data/364260/1/rwe-power-

460 ag/innovations/adele/Brochure-ADELE.pdf

461 [18] Leith, W. 2001. Geologic and Engineering Constraints on the Feasibility of Clandestine Nuclear 462 Testing by Decoupling in Large Underground Cavities. Department of the Interior U.S. Geological 463 Survey, Open file report, 01-28.

464 [19] Saylor, A. 2011. General Compression Looks at Energy Storage from a Different Angle. Online 465 article, uploaded February 3, 2011 - 3:36pm. https://energy.gov/articles/general-compression-looksenergy-storage-different-angle

[20] General Compression. 2014. Texas Dispatachable Wind 1, LLC. Company website: http://www.generalcompression.com/index.php/tdw1

[21] Economist. 2012. Energy technology: Better ways of storing energy are needed if electricity systems are to become cleaner and more efficient. Online article, Economist, Technology Quarterly: Q1 2012, uploaded Mar 3rd 2012. http://www.economist.com/node/21548495 [22] Warren, J.K. 2006. Evaporites: Sediments, Resources and Hydrocarbons. Berlin, Springer, 1036pp.

[23] Kepplinger, J., Crotogino, F., Donadei, S. \& Wohlers, M. 2011. Present Trends in Compressed Air Energy and Hydrogen Storage in Germany. SMRI Fall 2011 Technical Conference 3-4 October 2011 York, United Kingdom, 13pp.

[24] Aherne, S. \& Kelly, J. 2013. Project CAES Larne - An exploration program for compressed air energy storage in Northern Ireland. Solution Mining Research Institute (SMRI) Fall 2013 Technical Conference, Avignon, France, 30 September-1 October 2013, 11 pp.

[25] Gaelectric. 2015. Gaelectric energy storage: The missing link. Company newsletter available on line. Accessed November 14 ${ }^{\text {th }}$ 2015. http://www.gaelectric.ie/wpx/wp-content/uploads/2015/09/GaelectricSupplement-June-2015.pdf

[26] EPRI. 2003. EPRI-DOE Handbook of Energy Storage for Transmission \& Distribution Applications. Final report, December 2003 by the Electric Power Research Institute (EPRI) to US Department of Energy (DOE),PaloAlto,CA.512pp. http://www.sandia.gov/ess/publications/ESHB\%201001834\%20reduced\%20size.pdf

[27] Evans, D.J. \& Holloway, S. 2009. A review of onshore UK salt deposits and their potential for underground gas storage. In: Evans, D.J. and Chadwick, R.A. (eds) Underground gas storage: worldwide experiences and future development in the UK and Europe. Geological Society of London Special Publication, 313, 39-80.

[28] Warrington, G and eight others. 1980. A Correlation of Triassic rocks in the British Isles. Special

[29] Rees, J. G., and A. A. Wilson. 1998. British regional geology: geology of the country around Stokeon-Trent. London: Stationery Office.

[30] Howard, A S, Warrington, G, Ambrose, K, and Rees, J G. 2008. A formational framework for the Mercia Mudstone Group (Triassic) of England and Wales. British Geological Survey Research Report, $\mathrm{RR} / 08 / 04$.

[31] O'Brien, M. 2012. Gas Storage in the Cheshire Salt Deposits. Presentation at SMI Conference "Gas Storage", Copthorne Tara Hotel, London, 25-26 ${ }^{\text {th }}$ June 2012.

[32] Beutel, T. \& Black, S. 2005. Salt deposits and gas cavern storage in the UK with a case study of salt exploration in Cheshire. Oil Gas European Magazine, 1/2005, 31-35.

[33] Charnavel. Y. 2012. Illustration case in bedded salt: Stublach Gas Storage Project: Fundamentals of Salt Cavern Development. Solution Mining Research Institute (SMRI) Fall 2012 Meeting, Bremen, Germany, Technical Class, 30 September 2012, 19 pp. 
[34] Charnavel. Y., O’Donnell, J. \& Ryckelynck, T. 2015. Solution mining at Stublach. Solution Mining Research Institute (SMRI) Spring 2015 Technical Conference, Rochester, New York, 27-28 April, 14 pp.

[35] Howell, F.T., and P.L.Jenkins, 1976, Some aspects of the subsidences in the rocksalt districts of Cheshire, England: Proceedings of the $2^{\text {nd }}$ International Symposium on Land Subsidence, International Association of Hydrological Sciences, Publication no. 121, 507-520.

[36] Cooper, A.H., 2002. Halite karst geohazards (natural and man-made) in the United Kingdom. Environ. Geol., 42, 505-512.

[37] Wilson, A.A. 1993. The Mercia Mudstone Group (Trias) of the Cheshire Basin Proceedings of the Yorkshire Geological Society, 49, 171-188.

[38] Longley-Cook, W. A. n.d. Recent developments at Winsford salt mine, Cheshire, England:

Transactions of the Institution of Mining and Metallurgy Section A Mining industry 98(Jan-April) 1989 p63-67.

[39] Earp, J. R., B. J. Taylor, and D. Magraw. 1986. Geology of the country around Chester and Winsford: memoir for 1:50 000 geological sheet 109. London: H.M.S.O.

[40] Evans, W.B., Wilson, A.A., Taylor, B.J. \& Price, D. 1968. Geology of the country around Macclesfield, Congleton, Crewe and Middlewich. Memoirs of the Geological Survey of Great Britain, England and Wales Sheet 110.

[41] Evans, D.J., Williams, J.D.O., Hough, E. \& Stacey, A. 2011. The stratigraphy and lateral correlations of the Northwich and Preesall halites from the Cheshire Basin-East Irish Sea areas: implications for sedimentary environments, rates of deposition and the solution mining of gas storage caverns. Solution Mining Research Institute, Fall 2011 Technical Conference, York, United Kingdom, 3-4 October 2011, 1-28.

[42] HSE. 2016. Natural Gas Salt Cavity Storage - Guidance to Inspectors on Borehole and Cavern Design, Cavern Leaching and Operation of the Borehole and Cavern. SPC/ENFORCEMENT/185, September 2016, 14 pp. http://www.hse.gov.uk/foi/internalops/hid_circs/enforcement/spc185.pdf

[43] DeVries, K.L., Mellegard, K.D., Callahan, G.D. \& Goodman, W.M. 2005. Cavern roof stability for natural gas storage in bedded salt. Report prepared for United States Department of Energy, National Energy Technology Laboratory, Final report, 26 September 2002-31 March 2005. Topical Report, June 2005, RSI-1829, DE-FG26-02NT41651, 191 pp.

[44] Geostock, 2014. Halite Energy Gas Storage: Preesall Gas Storage Project - Revision of storage cavern design. Geostock report prepared for Halite Energy Gas Storage, GKF/0/J/0001, 25 pp.

[45] Mott MacDonald. 2014. Preesall Underground Gas Storage Facility: Updated Geological Summary Report, 2014. Report prepared for Halite Energy Group, May 2014, 169 pp.

[46] Durie, R.W. \& Jessen, F.W. 1964. The influence of surface features in the salt dissolution process. Society of Petroleum Engineers Journal, 4, 275-281.

[47] Field, L.P., Milodowski, A.E., Parkes, D. and Evans, D.J. 2017. Petrological and textural factors that may influence the dissolution of halite during the construction of salt caverns for the storage of natural gas and compressed air. British Geological Survey Commissioned Report, CR/13/069. 70pp.

[48] Evans, D.J., Kingdon, A., Hough, E., Reynolds, W. \& Heitmann, N. 2012. First use of resistivity borehole micro-imaging (FMI) to assess the sedimentology and structure of the Preesall Halite, NW England: implications for gas storage and CCS caprock assessments. Journal of the Geological Society, London, 169; 587-592.

[49] Schlumberger, 1991. Log interpretation Principles/Applications. Schlumberger Educational Services, Houston, $3^{\text {rd }}$ printing. (Original printed in 1989). 
548 [50] Wei He, Xing Luo, David Evans, Jonathan Busby, Seamus Garvey, Daniel Parkes, Jihong Wang, 549 2017. Exergy storage of compressed air in cavern and cavern volume estimation of the large-scale 550 compressed air energy storage system. Applied Energy, Volume 208, Pages 745-757. 


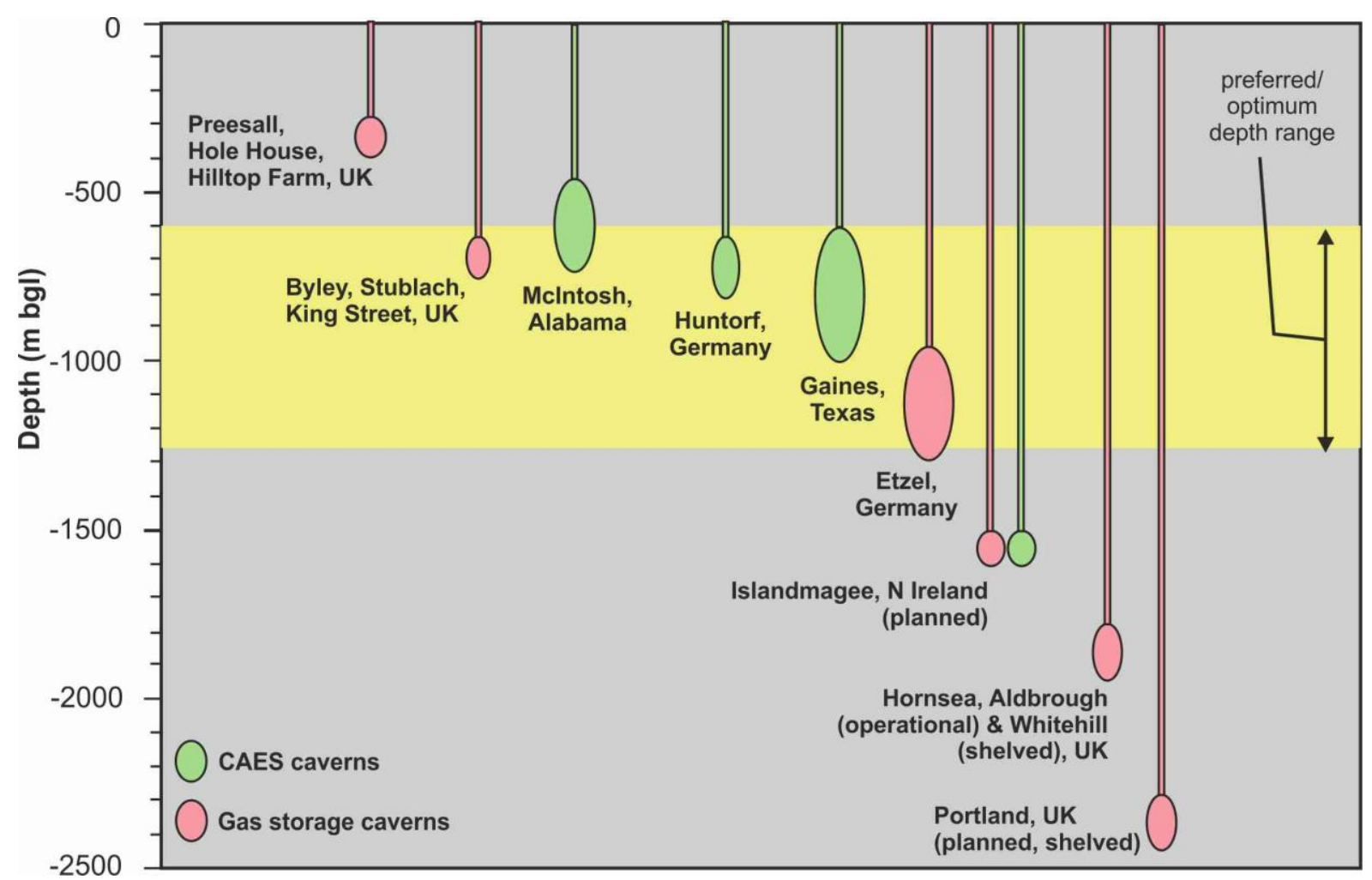

Figure 1. Schematic to illustrate the depths of operational and proposed global gas storage caverns in relation to operational and proposed global CAES caverns based on [23]. 

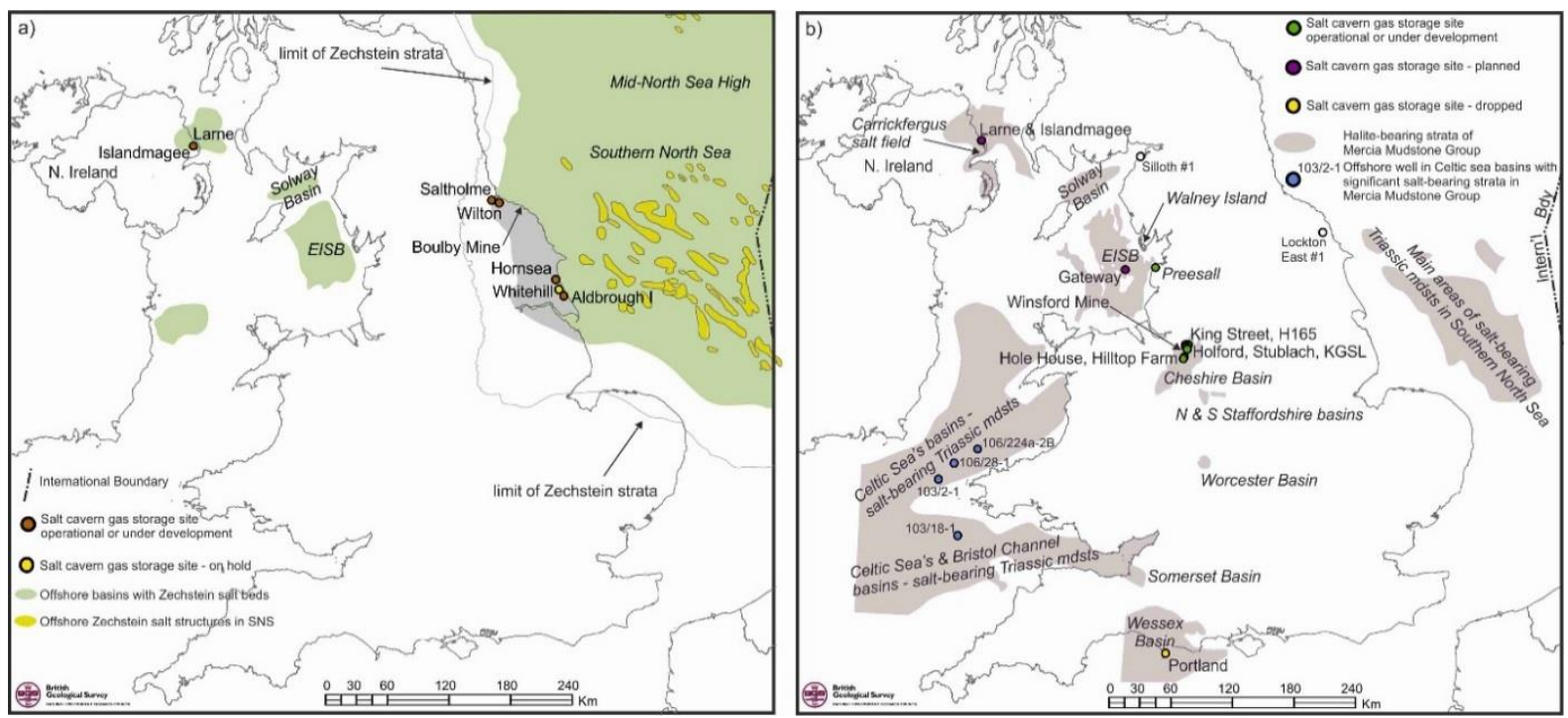

Figure 2. General map of UK Permian and Triassic basins containing massively bedded halite deposits and the location of the main UGS facilities (based upon [5]). a) principal Permian salt basins, b) principal Triassic salt basins - note thin, aerially restricted, onshore lateral equivalents of thick offshore Triassic halites, proved in boreholes in eastern England (e.g. Lockton East \#1), the Fylde and the Carlisle Basin in NW Cumbria (e.g. Silloth \#1), are not shown. Abbreviations: SNS - Southern North Sea, Intern'l Bdy - International Boundary 


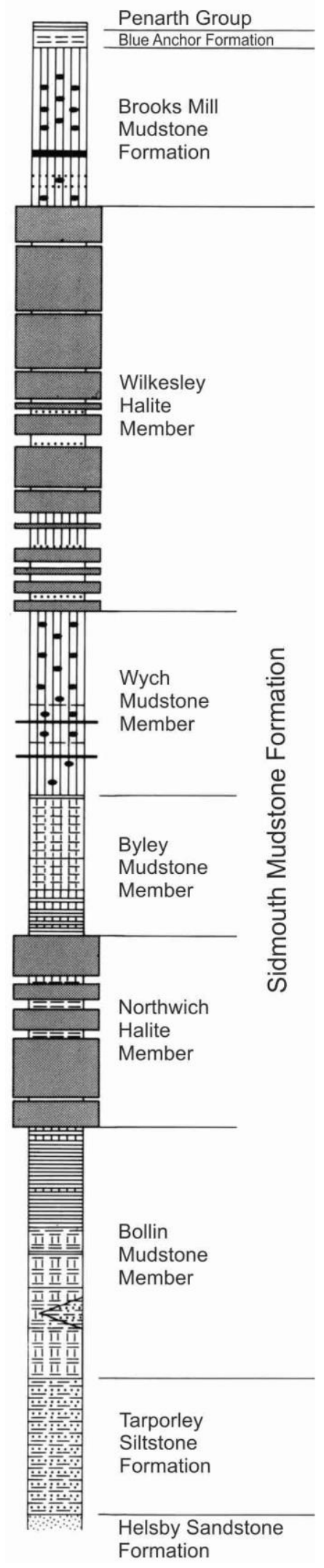

Figure 3. The succession in the Mercia Mudstone Group of the Cheshire Basin based upon $[28,29,30]$. 


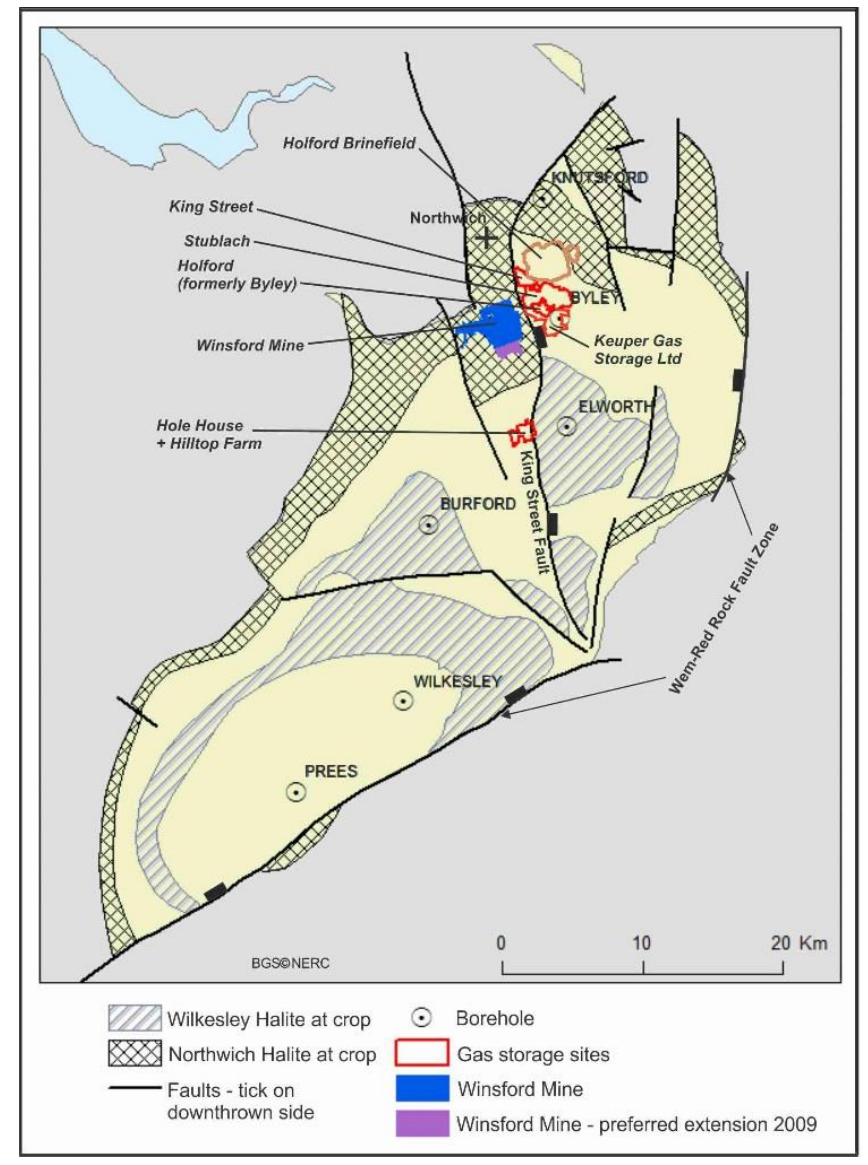

Figure 4. General location map of the two main bedded Triassic halites in the Cheshire Basin plus the deep boreholes, working Winsford mine and salt cavern gas storage sites based upon [27].

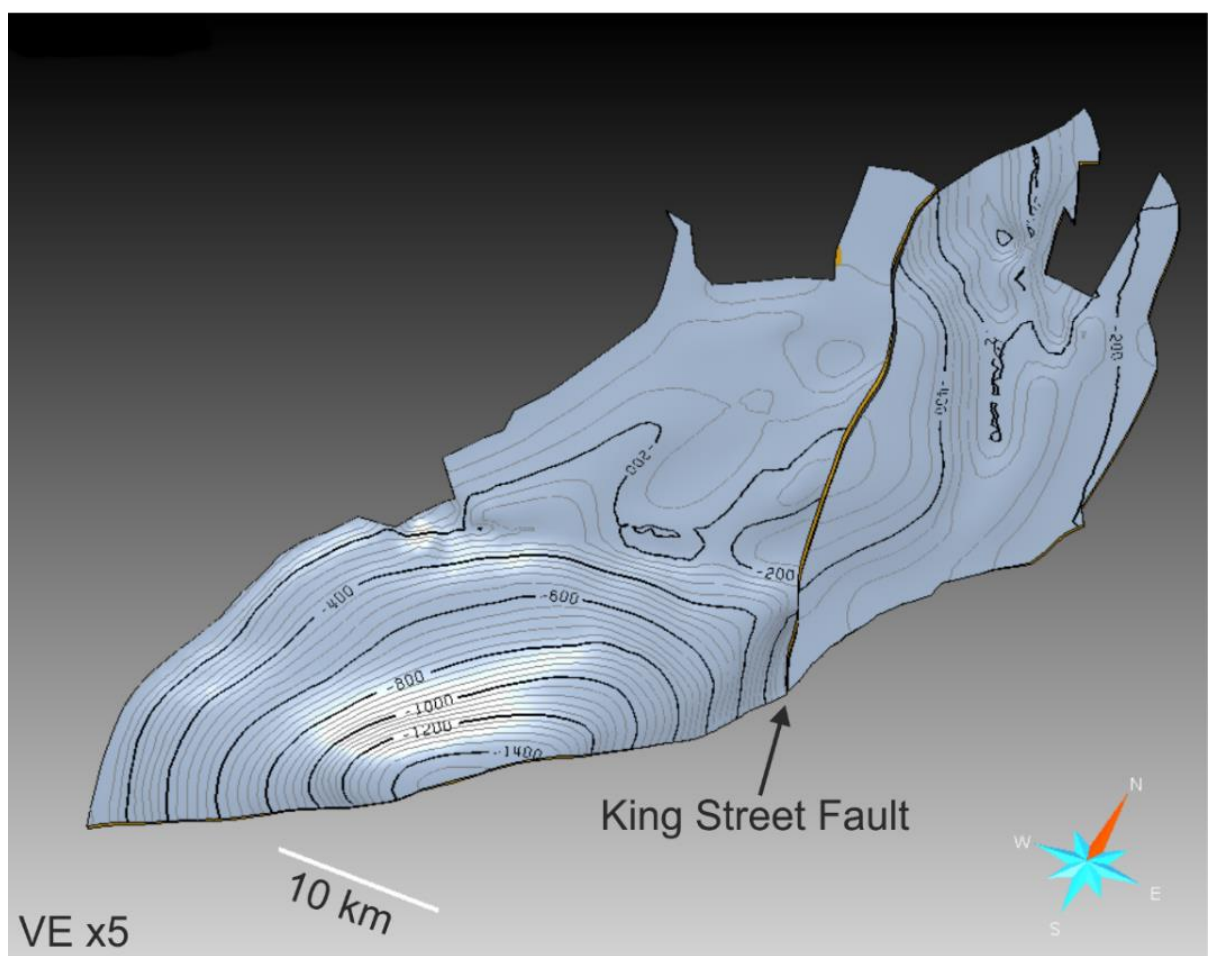

Figure 5. Screenshot of the GOCAD model of the depth to top of the Northwich Halite Member. Contours are in metres below ground level. 


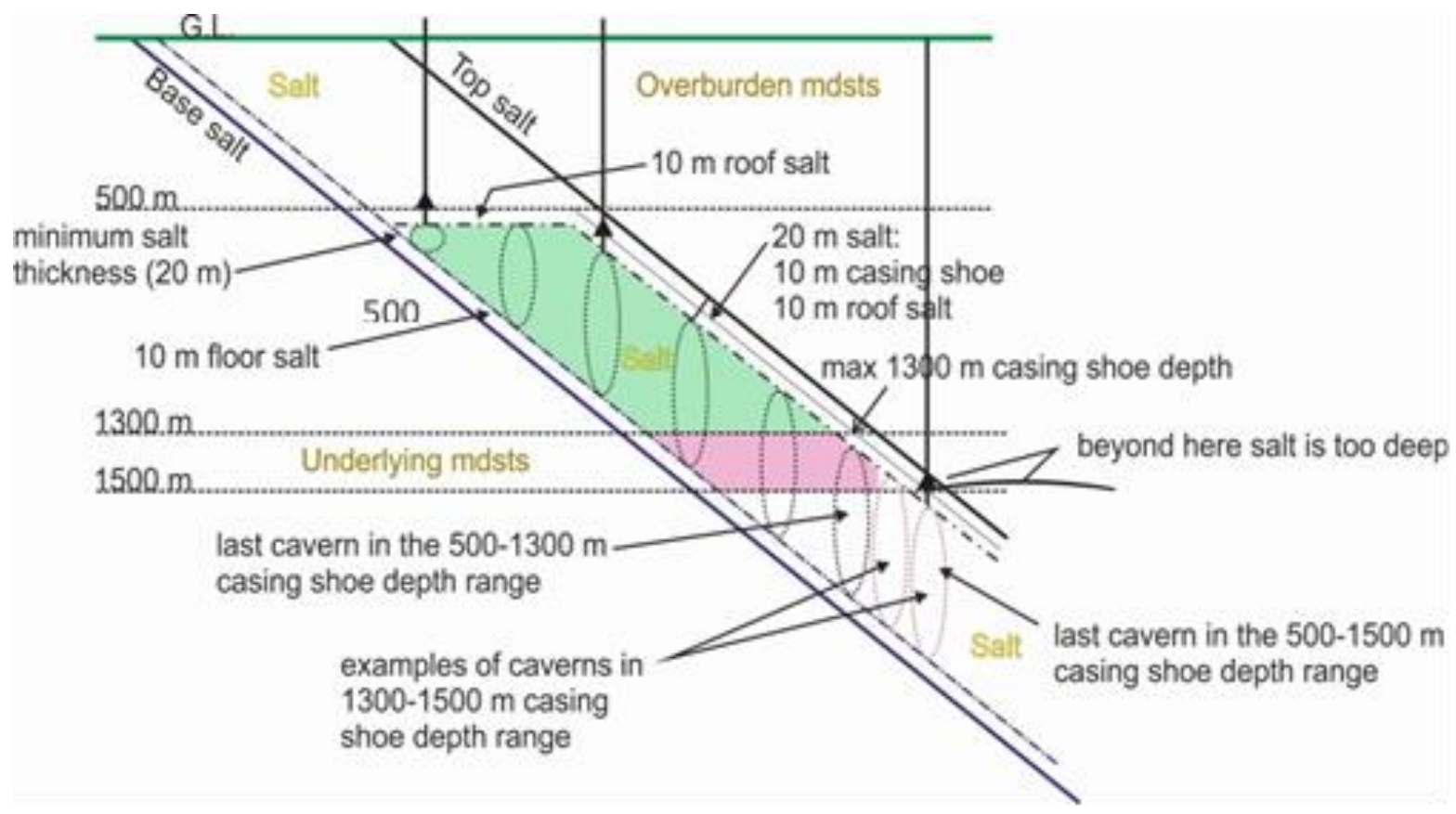

Figure 6. Illustration in section of the calculation of the volume of salt available for storage cavern construction in the depth ranges 500-1300 m and 500-1500 m, where casing shoe is set at $500 \mathrm{~m}$, where top halite is greater, a minimum of $10 \mathrm{~m}$ into the halite beds. 


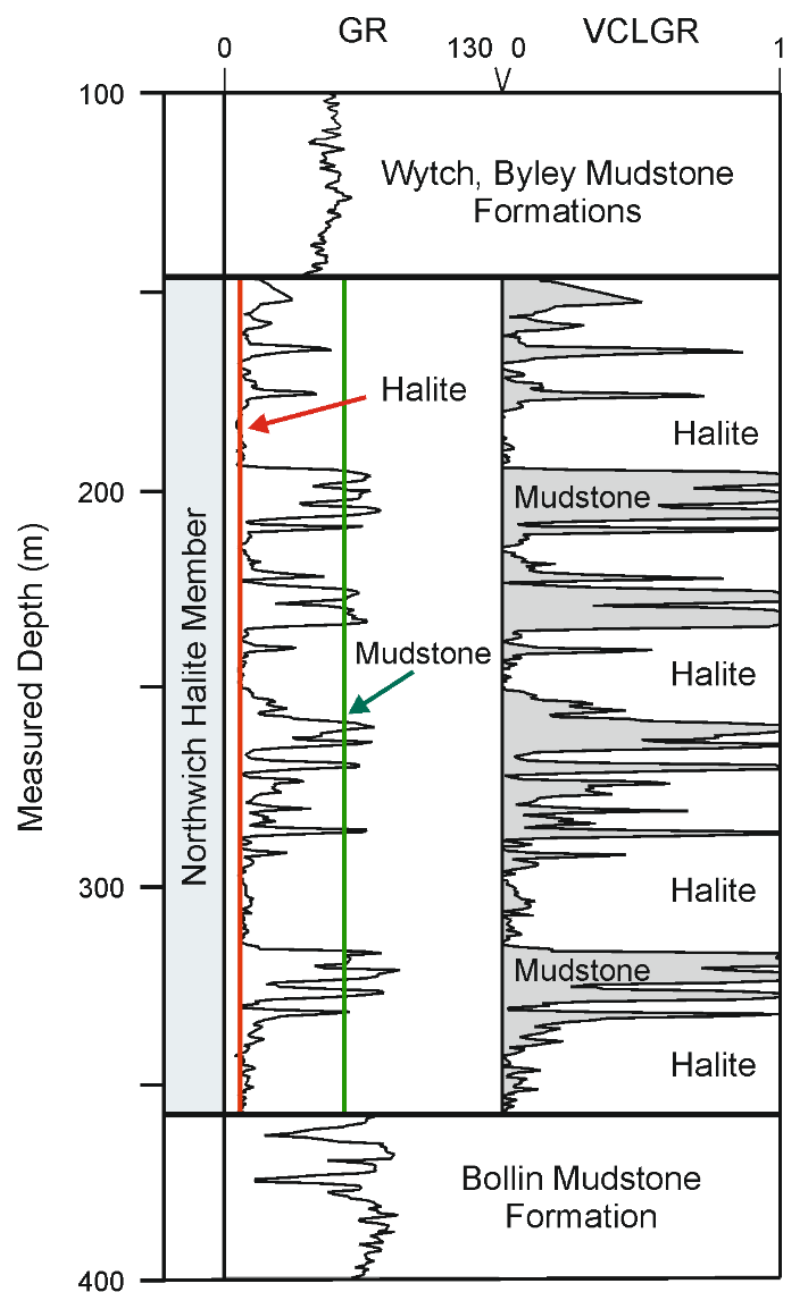

Figure 7. Image showing specification of clean 'halite' and 'clay' left track shows original GR $\log$ from Burford 1 well, while right-hand track displays normalised volume of clay log. 


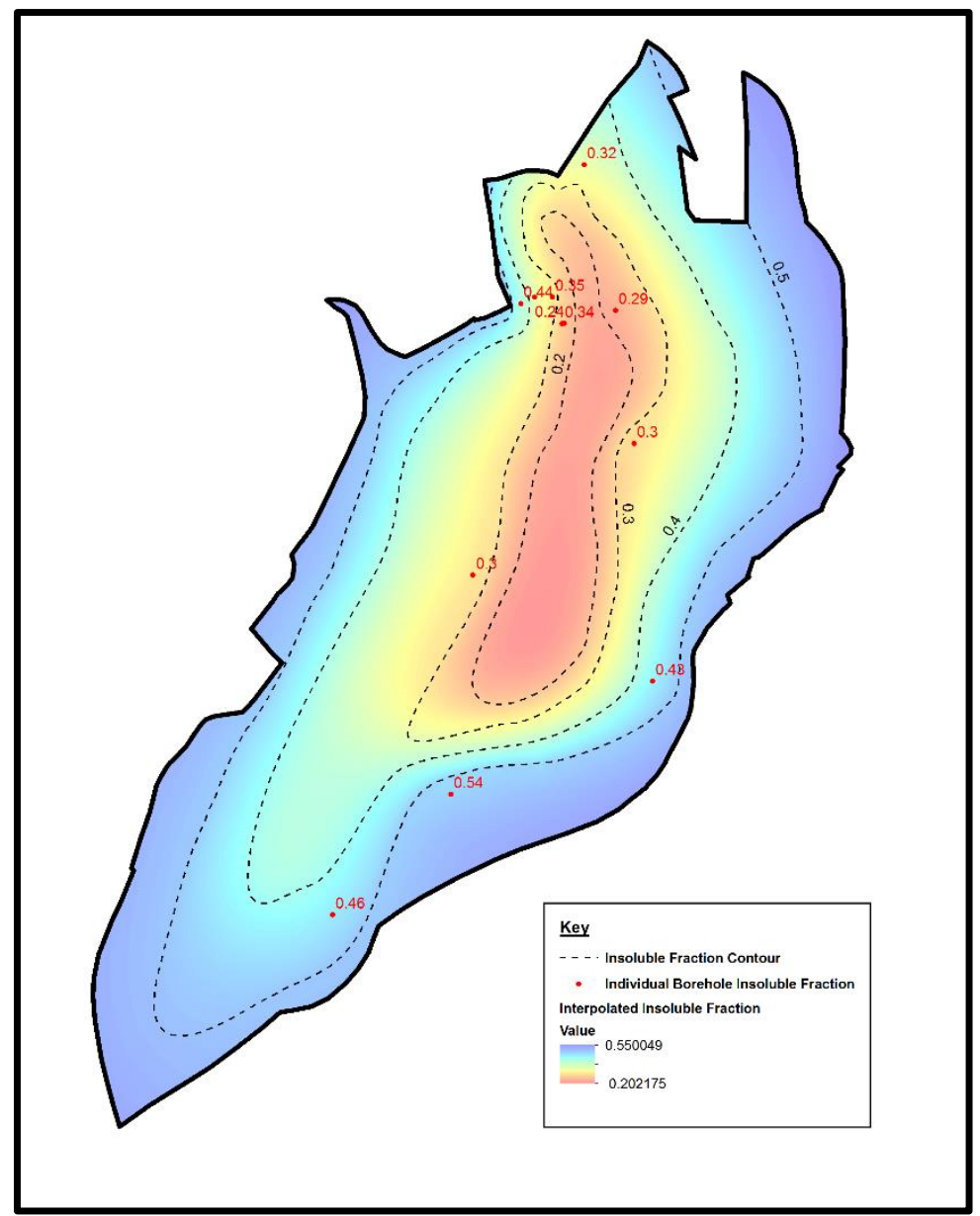

Figure 8. Mapped insoluble fraction and distribution in the Northwich Halite Member of the Cheshire Basin

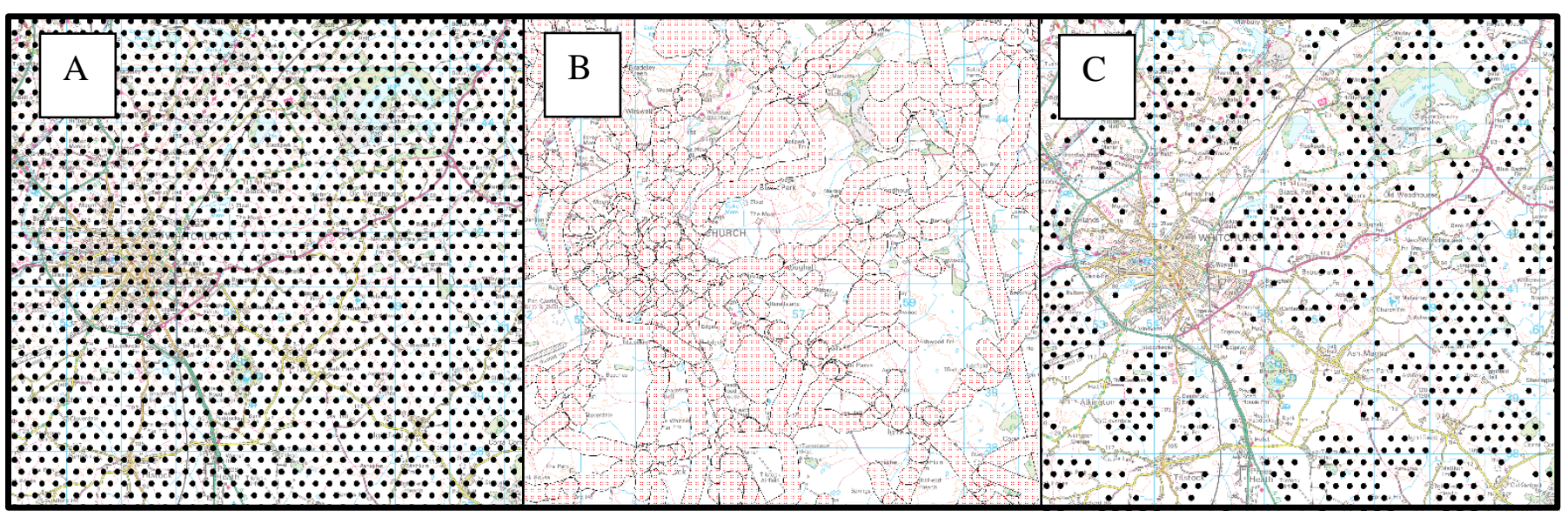

Figure 9. Example of buffers applied in an area of the Cheshire Basin to identify potential viable cavern locations and derive possible cavern volumes for CAES and exergy storage 
calculations. A - All caverns with no infrastructure consideration. B - Infrastructure buffers. C- Final caverns after removing caverns that are not viable due to lying under infrastructure.
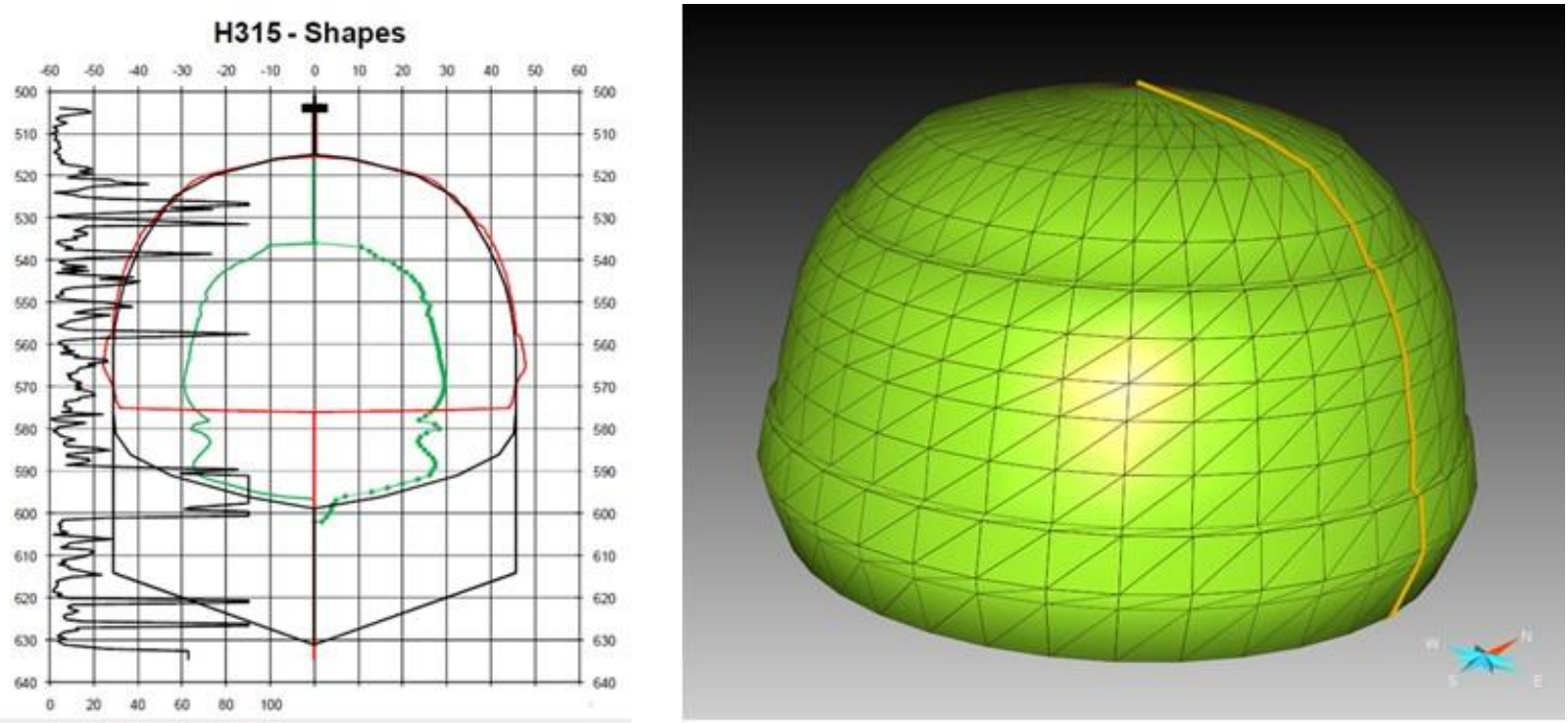

Figure 10. Examples of shape of cavern constructed in the Northwich Halite at Stublach based upon [23, 24]. Final 2D cavern shape from cavern H315 (left, red outline) and 3D cavern shape (right), constructed from 2D section (left, red outline). Illustrates the lost volume due to insoluble in the halite beds. 


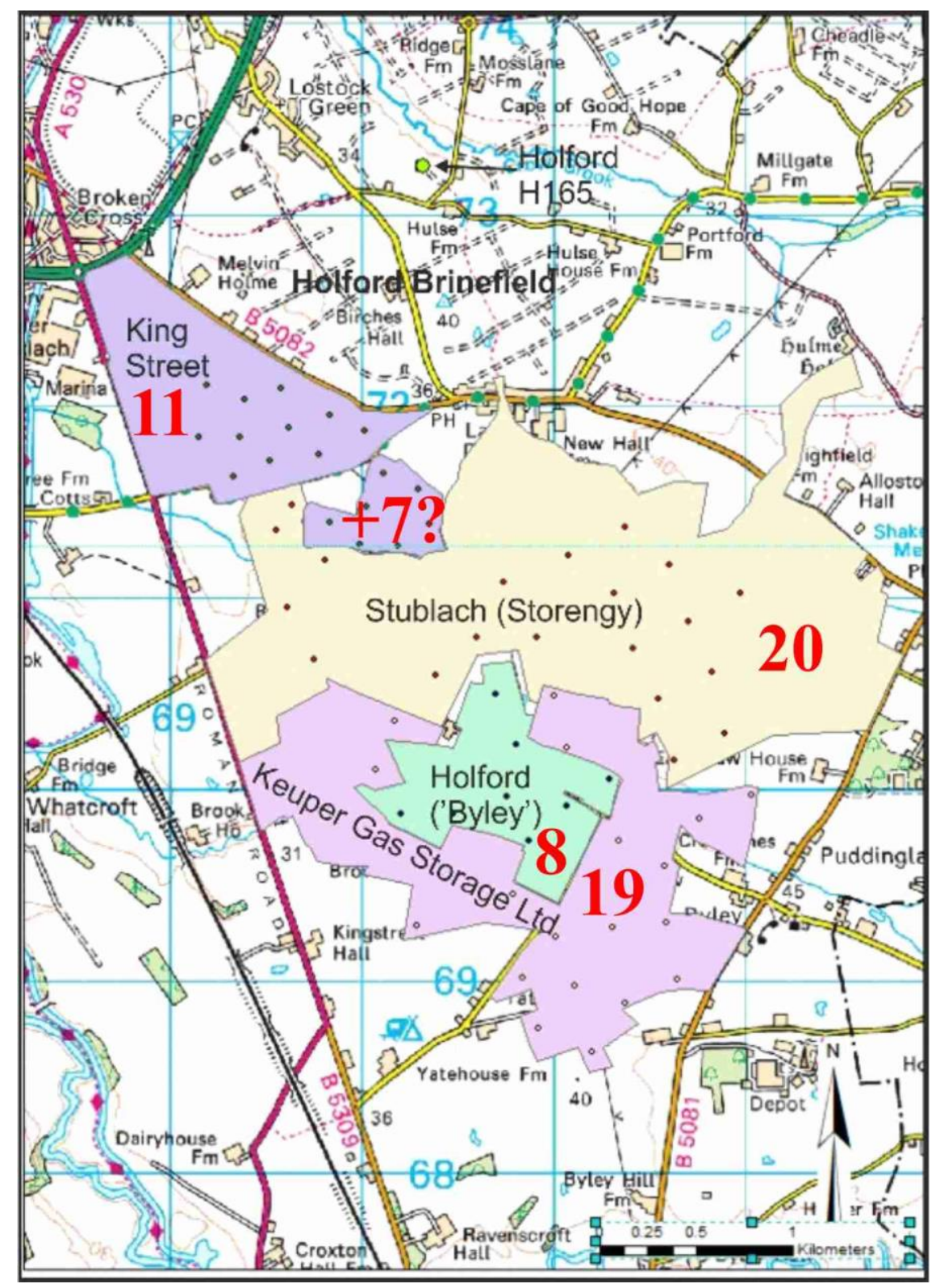

Figure 11. Illustration of the areas and cavern numbers of salt caver-hosted gas storage facilities in Cheshire (refer to Table 2). The number of caverns associated with the four storages illustrates the figures calculated for CAES are similar to those resources already developed for individual gas storage, illustrating the potential area that might be involved. 
Table 1. CAES capital costs after [26].

\begin{tabular}{|l|c|}
\hline Geological Storage Type & Storage/reserve capacity cost $\mathbf{( \$ / k W h )}$ \\
\hline Salt cavern - solution mining & $1-5$ \\
\hline Salt 'cavern' - dry mining & 10 \\
\hline Porous rock - aquifer & 0.1 \\
\hline Hard rock - existing mine & 10 \\
\hline Hard rock - excavated cavern & 30 \\
\hline Abandoned mine - limestone, coalmine etc. & 10 \\
\hline
\end{tabular}


Table 2. Summary of UK salt cavern gas storage facility design and operational parameters.

\begin{tabular}{|c|c|c|c|c|c|c|c|}
\hline \multicolumn{2}{|c|}{ Facility/Status/Operator } & \multirow{2}{*}{$\begin{array}{c}\begin{array}{c}\text { Number } \\
\text { of } \\
\text { caverns }\end{array} \\
9\end{array}$} & \multirow{2}{*}{$\begin{array}{c}\begin{array}{c}\text { Cavern } \\
\text { depths - } \\
\text { top/base (m, } \\
\text { bgl)) }\end{array} \\
\sim 1780-1830- \\
1880-1930\end{array}$} & \multirow{2}{*}{$\begin{array}{c}\begin{array}{c}\text { Pressure } \\
\text { range - } \\
\text { min./max. } \\
\text { (bar) }\end{array} \\
\text { Min }=120 \\
\text { Max }=270\end{array}$} & \multirow{2}{*}{$\begin{array}{c}\text { Cavern } \\
\text { volume - } \\
\text { physical }\left(\mathbf{m}^{3}\right)\end{array}$} & \multirow{2}{*}{$\begin{array}{c}\begin{array}{c}\text { Total } \\
\text { cavern } \\
\text { volume - } \\
\text { physical } \\
\text { (mcm) }\end{array} \\
\sim 1.98\end{array}$} & \multirow{2}{*}{$\begin{array}{c}\begin{array}{c}\text { Working } \\
\text { gas } \\
\text { volume } \\
\text { (mcm) }\end{array} \\
325\end{array}$} \\
\hline \multirow{7}{*}{ } & $\begin{array}{c}\text { Hornsea } \\
\text { (Scottish and } \\
\text { Southern Energy) }\end{array}$ & & & & & & \\
\hline & $\begin{array}{c}\text { Aldbrough I } \\
\text { (Statoil and Scottish } \\
\text { \& Southern Energy) }\end{array}$ & 9 & $\begin{array}{l}\sim 1780-1830- \\
1880-1930\end{array}$ & $\begin{array}{l}\operatorname{Min}=120 \\
\operatorname{Max}=270\end{array}$ & $\sim 270,000$ & $\sim 2.43$ & 325 \\
\hline & $\begin{array}{c}\text { Holford H165 } \\
\text { (Ineos Enterprises) }\end{array}$ & 1 & $350 / 420$ & $\begin{array}{l}\operatorname{Min}=\sim 70 \\
\operatorname{Max}=85\end{array}$ & 175,000 & 0.175 & 3.83 \\
\hline & $\begin{array}{l}\text { Hole House } \\
\text { (EDF Trading) }\end{array}$ & 4 & $300 / 400$ & $\begin{array}{c}\text { Not } \\
\text { available }\end{array}$ & Not available & $\begin{array}{c}\text { Not } \\
\text { available }\end{array}$ & $50-75$ \\
\hline & $\begin{array}{c}\text { Hilltop Farm/Hole } \\
\text { House ext. } \\
\text { (EDF Trading) }\end{array}$ & 10 & $\sim 240-380$ & $\begin{array}{l}\operatorname{Min}=29 \\
\operatorname{Max}=45\end{array}$ & $\begin{array}{l}600,000- \\
650,000\end{array}$ & $\sim 6.25$ & 100 \\
\hline & $\begin{array}{c}\text { Holford } \\
\text { (EON Gas Storage } \\
\text { UK) }\end{array}$ & 8 & $\begin{array}{c}570-610 / 670- \\
700\end{array}$ & $\begin{array}{c}\operatorname{Min}=40 \\
\operatorname{Max}=105\end{array}$ & $\sim 370,000$ & $\sim 2.96$ & 160 \\
\hline & $\begin{array}{c}\text { Stublach } \\
\text { (Storengy) }\end{array}$ & 20 & $\sim 500 / 600$ & $\begin{array}{c}\operatorname{Min}=30 \\
\operatorname{Max}=101\end{array}$ & $\sim 330,000$ & $\sim 6.60$ & 400 \\
\hline \multirow{7}{*}{ 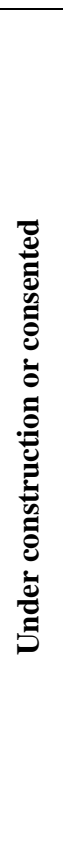 } & $\begin{array}{c}\text { Gateway (Gateway } \\
\text { Gas Storage Ltd) }\end{array}$ & 20 & $\sim 624$ & $\begin{array}{c}\operatorname{Min}=36 \\
\operatorname{Max}=120\end{array}$ & $\sim 1,000,000$ & $\sim 20$ & 1500 \\
\hline & $\begin{array}{c}\text { Islandmagee } \\
\text { (Islandmagee } \\
\text { Storage Limited) }\end{array}$ & 7 & $\sim 1500$ & $\begin{array}{l}\operatorname{Min}=120 \\
\operatorname{Max}=250\end{array}$ & 480,000 & $\sim 3.36$ & 500 \\
\hline & $\begin{array}{l}\text { Whitehill (EON Gas } \\
\text { Storage UK) }\end{array}$ & 10 & $\sim 1730-1830$ & $\begin{array}{l}\operatorname{Min}=100 \\
\operatorname{Max}=345\end{array}$ & 250,000 & $\sim 2.50$ & 400 \\
\hline & $\begin{array}{c}\text { King Street Energy } \\
\text { (King Street Energy } \\
\text { Ltd) }\end{array}$ & $11(+7 ?)$ & $\sim 320-420$ & $\begin{array}{c}\text { Min }=\text { not } \\
\text { known } \\
\text { Max }=66\end{array}$ & $\begin{array}{l}500,000- \\
850,000\end{array}$ & $\sim 5.50$ & $348-630$ \\
\hline & $\begin{array}{l}\text { Preesall (Halite } \\
\text { Energy Ltd) }\end{array}$ & 19 & $\begin{array}{c}\text { 340-456/413- } \\
618\end{array}$ & $\begin{array}{l}\operatorname{Min}=33 \\
\operatorname{Max}=92\end{array}$ & $\begin{array}{l}58,000- \\
860,000\end{array}$ & 6.8 & 324 \\
\hline & $\begin{array}{c}\text { Keuper Gas Storage } \\
\text { (Keuper Gas } \\
\text { Storage Ltd) }\end{array}$ & 19 & $\sim 650-750$ & $\begin{array}{l}\text { Min. }=43.8 \\
\text { Max. }=123\end{array}$ & 314,000 & $\sim 5.97$ & 500 \\
\hline & $\begin{array}{l}\text { Portland (Portland } \\
\text { Gas) }\end{array}$ & 8 & $\sim 2400 / 2500$ & $\begin{array}{c}\text { Min = brine } \\
\text { hydrostatic } \\
\text { (halmostatic) } \\
\text { pressure } \\
\text { Max }=440\end{array}$ & $\sim 250,000$ & 2.00 & 1000 \\
\hline \multicolumn{2}{|c|}{ Totals } & 155 & & & $5,159,000$ & 66.53 & 5,886 \\
\hline
\end{tabular}

Table 3. Summary of cavern numbers and volumes for the various depth ranges 250-1500 m, using two different insolubles values to calculate remaining cavern (physical) volumes. Volumes quoted are in million cubic metres ( $\mathrm{mcm})$. 


\begin{tabular}{|c|c|c|c|c|c|c|c|c|c|c|c|c|c|}
\hline & & \multicolumn{12}{|c|}{ Depths of casing shoe } \\
\hline & & \multicolumn{3}{|c|}{$250-1300 \mathrm{~m}$} & \multicolumn{3}{|c|}{$250-1500 \mathrm{~m}$} & \multicolumn{3}{|c|}{$500-1300 \mathrm{~m}$} & \multicolumn{3}{|c|}{$500-1500 \mathrm{~m}$} \\
\hline & & $\begin{array}{l}\text { Range } \\
(\mathrm{mcm})\end{array}$ & $\begin{array}{c}\text { Total } \\
(\mathrm{mcm})\end{array}$ & Number & $\begin{array}{l}\text { Range } \\
(\mathrm{mcm})\end{array}$ & $\begin{array}{c}\text { Total } \\
(\mathrm{mcm})\end{array}$ & Number & $\begin{array}{l}\text { Range } \\
(\mathrm{mcm})\end{array}$ & $\begin{array}{c}\text { Total } \\
(\mathrm{mcm})\end{array}$ & Number & $\begin{array}{l}\text { Range } \\
(\mathrm{mcm})\end{array}$ & $\begin{array}{c}\text { Total } \\
(\mathrm{mcm})\end{array}$ & Number \\
\hline \multirow{2}{*}{ 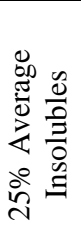 } & $\underset{\text { 咅 }}{\bar{z}}$ & $\begin{array}{c}0.075- \\
1.015\end{array}$ & 7,710 & 16,151 & $\begin{array}{c}0.075- \\
1.015\end{array}$ & 7,930 & 16,607 & $\begin{array}{c}0.076- \\
0.882\end{array}$ & 3,750 & 7,356 & $\begin{array}{c}0.076- \\
0.882\end{array}$ & 3,980 & 7,835 \\
\hline & 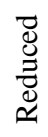 & $\begin{array}{r}0.076- \\
0.982\end{array}$ & 1,830 & 3,880 & $\begin{array}{c}0.076- \\
0.982\end{array}$ & 1,900 & 4,034 & $\begin{array}{c}0.086- \\
0.877\end{array}$ & 992.0 & 1,936 & $\begin{array}{c}0.086- \\
0.877\end{array}$ & 1,070 & 2,099 \\
\hline \multirow{2}{*}{ 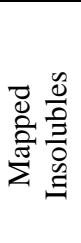 } & $\underset{\bar{I}}{\bar{\Xi}}$ & $\begin{array}{r}0.036- \\
1.032\end{array}$ & 6,200 & 16,151 & $\begin{array}{c}0.036- \\
1.032\end{array}$ & 6,320 & 16,607 & $\begin{array}{c}0.045- \\
0.919\end{array}$ & 2,920 & 7,356 & $\begin{array}{c}0.045- \\
0.919\end{array}$ & 3,050 & 7,835 \\
\hline & 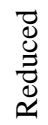 & $\begin{array}{c}0.036- \\
0.994\end{array}$ & 1,400 & 3,880 & $\begin{array}{c}0.036- \\
0.994\end{array}$ & 1,440 & 4,034 & $\begin{array}{c}0.045- \\
0.918\end{array}$ & 734.0 & 1,936 & $\begin{array}{c}0.045- \\
0.918\end{array}$ & 777.0 & 2,099 \\
\hline
\end{tabular}

